\title{
Mechanical properties and development of supersolvus heat treated new nickel base superalloy AD730 ${ }^{\mathrm{TM}}$
}

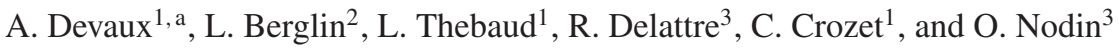 \\ ${ }^{1}$ Aubert \& Duval, BP. 1, 63770 Les Ancizes Cedex, France \\ 2 Siemens Industrial Turbomachinery AB, 61283 Finspong, Sweden \\ ${ }^{3}$ Aubert \& Duval, 75 boulevard de la Libération, BP. 173, 09102 Pamiers Cedex, France
}

\begin{abstract}
The enhancement of efficiency in power generation gas turbine requires the development of new superalloys capable of withstanding higher temperatures. The development of AD730 ${ }^{\mathrm{TM}}$ superalloy was achieved to provide to this new cast \& wrought $(\mathrm{C} \& \mathrm{~W})$ superalloy a higher combination between mechanical properties, microstructural stability and cost than that of other C\&W superalloys with a temperature capability up to $750^{\circ} \mathrm{C}$. Supersolvus heat-treatment of $\mathrm{AD} 730^{\mathrm{TM}}$ was studied to improve the creep properties of fine grain $\mathrm{AD} 730^{\mathrm{TM}}$ superalloy which were not high enough to reach the foreseen conditions of future power generation gas turbine disks. Firstly, the grain growth was studied to select the supersolvus temperature $1120^{\circ} \mathrm{C}$ and to obtain a homogeneous coarse grain microstructure. Then, various supersolvus heat-treatments with different cycles were tested and applied on a forged pancake with a section representative of power generation gas turbine disk. The average grain size was evaluated to be close to $200 \mu \mathrm{m}$ for all heat-treatments. Tensile, creep, fatigue and fatigue crack growth tests were performed to compare the various heat-treatments. FEG-SEM examinations were also realized to discuss the relationships between heat-treatment, intragranular gamma prime precipitation and mechanical properties. Finally, a comparison made with other supersolvus heat treated C\&W superalloys shows that $\mathrm{AD} 730^{\mathrm{TM}}$ properties obtained with coarse grain microstructure are at the expected level and enable applications for power generation gas turbine discs.
\end{abstract}

\section{Introduction}

The energy system is in transformation. Fuel efficiency will be the new greenhouse standard and power systems with low efficiency will not be preferred or even banned by legislation. To meet this requirement, stationary gas turbines will operate with higher temperatures, using new technology. This can only be done utilizing new gas turbine materials. Materials with better creep properties and better oxidation resistance must be developed to withstand the higher temperatures. Gas turbine discs must be able to operate at temperatures beyond the temperature limitations of IN718, i.e. operate above $650{ }^{\circ} \mathrm{C}$. The transformation includes more changes. The increasing share of distributed generation and renewable energy by means of wind power and solar power has created an energy mix that did not exist in the past. New and old power plants will interact on the energy market to fulfil demands and needs. However, this new mix also means that old power plants must be able to cover up when the wind suddenly ceases e.g. For stationary gas turbines, and other old production units, the operation will become more flexible.

To meet the requirement to be flexible, gas turbines will start and stop more often. Cyclic operation will become a new standard, and will set new requirements for important parts, as the rotating turbine discs. This

\footnotetext{
${ }^{\text {a }}$ Corresponding author: alexandre.devaux@erametaubertduval.com
}

means that the cyclic lifetime will be depending on crack propagation and not as today, purely relies on cycles to crack initiation. For a superalloy, the fatigue crack propagation rate will be determined by metallurgical and micro structural properties; the grain size, the $\gamma^{\prime}$ size and distribution, the resistance to environmental influence, and the chemical composition.

$\mathrm{AD} 730^{\mathrm{TM}}$ produced by the conventional $\mathrm{C} \& \mathrm{~W}$ processes has an attractive combination of manufacturing costs and mechanical properties at higher temperatures [1-3]. For future applications in gas turbines, improved cyclic, creep and oxidation properties will certainly be needed.

\section{Material and experimental procedure}

Triple melt 10 " billet in $\mathrm{AD} 730^{\mathrm{TM}}$ was used to forge a pancake with a diameter and a thickness respectively equal to $625 \mathrm{~mm}$ and to $100 \mathrm{~mm}$.

The chemistry of the billet is in Table 1 . The pancake was cut into three equal portions and heat-treated with different sequences as indicated in Table 2. Coupons were taken from each portion to perform tensile, creep, fatigue and fatigue crack growth rates and to identify the best sequence in regard to the foreseen expectations.

Regarding the gamma prime solvus of AD730, which is close to $1100^{\circ} \mathrm{C}$, a solution heat treatment made at $1120^{\circ} \mathrm{C}$ was selected to achieve a homogeneous and

This is an Open Access article distributed under the terms of the Creative Commons Attribution License 4.0, which permits unrestricted use, distribution, and reproduction in any medium, provided the original work is properly cited. 


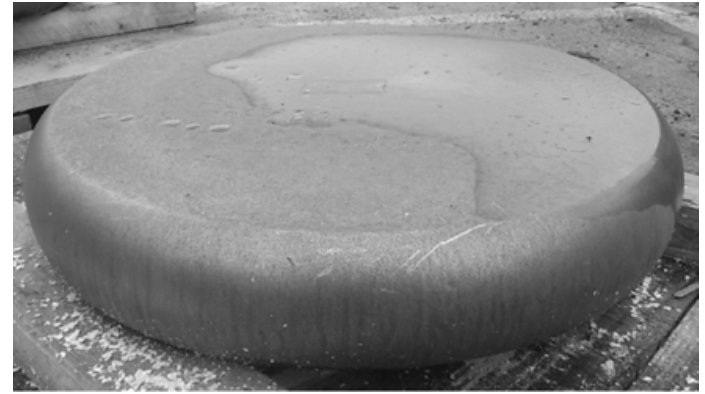

Figure 1. Pancake forged from 10" triple melt billet.

Table 1. Pancake forged from 10" triple melt billet Chemistry of 10 " billet (wt $\%)$.

\begin{tabular}{llllll}
\hline $\mathbf{N i}$ & $\mathbf{F e}$ & $\mathbf{C r}$ & $\mathbf{C o}$ & Mo & $\mathbf{W}$ \\
\hline Base & 4.15 & 15.83 & 8.28 & 2.86 & 2.6 \\
\hline $\mathbf{A l}$ & $\mathbf{T i}$ & $\mathbf{N b}$ & $\mathbf{B}$ & $\mathbf{C}$ & $\mathbf{Z r}$ \\
\hline 2.31 & 3.44 & 1.1 & 0.011 & $<0.02$ & 0.035 \\
\hline
\end{tabular}

coarse grain size [3]. A poor and insufficient ductility was expected with a coarse grain microstructure obtained with a high cooling rate from $1120^{\circ} \mathrm{C}$ followed by an aging made at a temperature close to the peak-aging temperature $\left(760^{\circ} \mathrm{C}\right)$. It is actually known that a coarse grain microstructure devoid of primary gamma prime precipitates and highly strengthened by fine intragranular gamma prime precipitates would be detrimental for ductility. It is the reason why different heat-treatment sequences were investigated after the supersolvus solution made at $1120^{\circ} \mathrm{C}$ to improve the mechanical properties and to preserve a good ductility at high temperature (Table 2).

\section{Microstructure}

As shown in Fig. 2 and Table 2, similar grain sizes were obtained for heat-treatments $\mathrm{A}, \mathrm{B}$ and $\mathrm{C}$ due to the same supersolvus cycle $\left(1120^{\circ} \mathrm{C} / 4 \mathrm{~h}\right)$ and the same duration above the gamma prime solvus. Primary gamma prime precipitates were mainly dissolved. Only some remaining particles were observed in the interdendritic regions where the gamma prime solvus is slightly higher.

Heat-treatment $\mathrm{A}$ is the combination of a high cooling rate after solution heat-treatment and a high aging temperature which was expected to coarsen the fine gamma prime precipitates, especially the tertiary ones, formed during the oil quenching. As shown in Fig. 2, only one $\gamma^{\prime}$ population was observed inside the grain. It strongly suggests that the finest tertiary $\gamma^{\prime}$ precipitates were dissolved during the aging at $840^{\circ} \mathrm{C}$ as reported on $\mathrm{PM}$ (powder metallurgy) superalloys above $800^{\circ} \mathrm{C}$ [4].

Heat-treatment B consists in applying a lower cooling rate after solution heat-treatment in order to obtain coarser secondary gamma prime precipitates than those obtained with heat-treatment $\mathrm{A}$. Then, a low aging temperature was chosen to avoid an excessive growth and dissolution of tertiary gamma prime precipitates. Consequently, in comparison with heat-treatment A, coarser secondary gamma prime precipitates and finer tertiary gamma prime precipitates were observed.
Heat-treatment $\mathrm{C}$ presents two solution heat-treatment steps. The first one is dedicated to the grain growth and followed by air cooling. The second one is made below gamma prime solvus and followed by a high cooling rate in order to obtain fine secondary and tertiary gamma prime precipitations during quenching. This second solution heat-treatment leads to the presence of cuboidal shape gamma prime precipitates which results from the coarsening of secondary gamma prime precipitates formed during the air cooling after the first solution heat-treatment at $1120^{\circ} \mathrm{C}$. The amount of these precipitates is not negligible and should be equal to the gamma prime fraction at the equilibrium at $1080^{\circ} \mathrm{C}$ which can be estimated to be close to $6 \%$ according to ThermoCalc calculations (Fig. 3). Secondary and tertiary gamma prime precipitates were observed between the cuboidal gamma prime precipitates and were formed during oil quenching. These precipitates are finer than those observed for heattreatment $\mathrm{A}$ and $\mathrm{B}$ due to the high cooling rate and the lower solution temperature. The amount of intergranular precipitates is also theoretically lower and close to the total amount of gamma prime minus the amount of cuboidal gamma prime. Based upon ThermoCalc calculations, the amount of fine secondary and tertiary precipitates in heattreatment $\mathrm{C}$ is estimated to be close to $32 \%$.

\section{Mechanical properties}

Tensile tests at various temperatures, creep tests, fatigue tests and fatigue crack growth tests were performed on each treatment to evaluate the effect of microstructure on mechanical properties.

A comparison was established with results obtained on a pancake with a similar thickness made in 718Plus [5]. Heat-treatment applied to the 718Plus supersolvus forged pancake was a presolutioning at $870{ }^{\circ} \mathrm{C} / 12 \mathrm{~h} / \mathrm{AC}$ followed by a solution heat-treatment at $982^{\circ} \mathrm{C} / 1 \mathrm{~h} / \mathrm{OQ}$ and an aging $788^{\circ} \mathrm{C} / 8 \mathrm{~h} / \mathrm{FC}$ to $704^{\circ} \mathrm{C} / 8 \mathrm{~h} / \mathrm{AC}$. Grain size was close to ASTM 7. Results obtained on cast \& wrought U720 were also used for comparison [6]. The pancake had a similar thickness $(80 \mathrm{~mm})$ and was supersolvus heattreated as follows : $1157^{\circ} \mathrm{C} / 4 \mathrm{~h} / \mathrm{AC}+1090^{\circ} \mathrm{C} / 4 \mathrm{~h} / \mathrm{OQ}+$ $845^{\circ} \mathrm{C} / 24 / \mathrm{AC}+760^{\circ} \mathrm{C} / 16 \mathrm{~h} / \mathrm{AC}$. Grain size was ASTM 0 with some bands ASTM 10.

As shown in Fig. 4, similar ultimate tensile strengths were obtained for different heat-treatments A, B and C suggesting that ultimate tensile strength is less sensitive to microstructural variations than yield strength. Yield strength of heat-treatment $\mathrm{C}$ is significantly more important than those of heat-treatments $\mathrm{A}$ and $\mathrm{B}$ which are quite equivalent (Fig. 5). It is well established in superalloys that fine intragranular (secondary and tertiary) gamma prime precipitates promote high yield strength [3,7-9]. Consequently, the higher YS obtained with heat-treatment $\mathrm{C}$ can be easily explained by the finer gamma prime precipitates within the grains observed after this heat-treatment. As secondary precipitates of heattreatment $\mathrm{A}$ are finer than those of heat-treatment B, it strongly suggests that the dissolution and the lack of tertiary gamma prime precipitates on microstructure obtained with heat-treatment A affects the yield strength. A significant increase of yield strength was observed for 

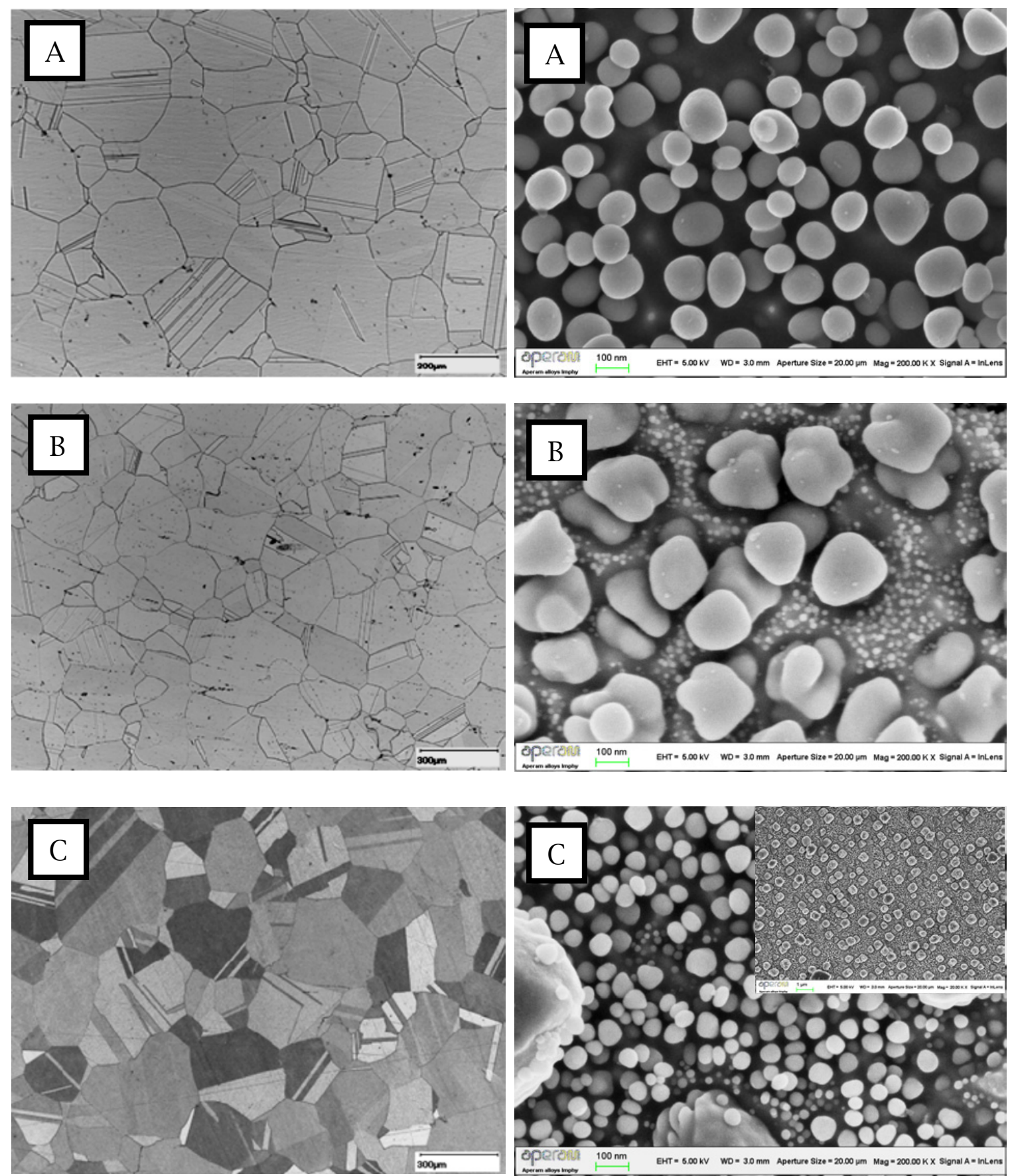

Figure 2. Microstructures observed after heat-treatments A, B and C.

heat-treatment $\mathrm{A}$ at $700{ }^{\circ} \mathrm{C}$ and $750{ }^{\circ} \mathrm{C}$. It is supposed to be the consequence of the higher aging temperature $\left(840^{\circ} \mathrm{C}\right)$ which promotes the precipitation of a higher gamma prime fraction in the $650-750{ }^{\circ} \mathrm{C}$ temperature range. Elongation and ductility are similar between all heat-treatment and remains above $10 \%$ up to $800{ }^{\circ} \mathrm{C}$ (Fig. 6).

Tensile strength of U720 and 718Plus superalloys is quite similar to that measured with heat-treatment $\mathrm{A}$ especially at high temperature. Higher tensile properties at room temperature are obtained with 718 Plus probably in relation with a finer grain size. These tensile properties obtained on 718Plus are in good agreement with those reported in literature after supersolvus forging and presolutioning [10].

Creep tests were performed in air at $700^{\circ} \mathrm{C}$ under a stress equal to $600 \mathrm{MPa}$ for various heat-treatments. As shown on Fig. 7, a higher steady creep rate was obtained with heat-treatment A due to the lack of tertiary gamma prime precipitates between the secondary ones. This tendency was not observed with stress-rupture tests performed at $800{ }^{\circ} \mathrm{C}$ under a stress of $300 \mathrm{MPa}$. Similar creep lives were actually obtained for all heat-treatments in these conditions as shown in Fig. 8. It is suggested that dissolution of tertiary gamma prime precipitates has also 
Table 2. Heat-treatment sequences tested and microstructures (grain and gamma prime sizes) obtained.

\begin{tabular}{ccccc}
\hline Reference & Solution heat-treatment & Aging & Grain size & $\begin{array}{c}\text { Intragranular } \\
\gamma^{\prime} \text { diameter }\end{array}$ \\
\hline A & $1120^{\circ} \mathrm{C} / 4 \mathrm{~h} /$ Oil Quench $\left(85^{\circ} \mathrm{C} / \mathrm{min}\right)$ & $840^{\circ} \mathrm{C} / 16 \mathrm{~h} /$ Air & ASTM 1.5 & $114 \mathrm{~nm}$ \\
\hline B & $1120^{\circ} \mathrm{C} / 4 \mathrm{~h} /$ Gas Quench $\left(60^{\circ} \mathrm{C} / \mathrm{min}\right)$ & $760^{\circ} \mathrm{C} / 16 \mathrm{~h} /$ Air & ASTM 1.5 & $184 \mathrm{~nm}$ and 24 mm \\
\hline $\mathrm{C}$ & $1120^{\circ} \mathrm{C} / 4 \mathrm{~h} /$ Air Cooled $\left(25^{\circ} \mathrm{C} / \mathrm{min}\right)$ & $760^{\circ} \mathrm{C} / 16 \mathrm{~h} /$ Air & ASTM 1.5 & $478 \mathrm{~nm}, 65 \mathrm{~nm}$ and $24 \mathrm{~nm}$ \\
& $1080^{\circ} \mathrm{C} / 4 \mathrm{~h} /$ Oil Quench $\left(100^{\circ} \mathrm{C} / \mathrm{min}\right)$ & & & and $24 \mathrm{~nm}$ \\
\hline
\end{tabular}

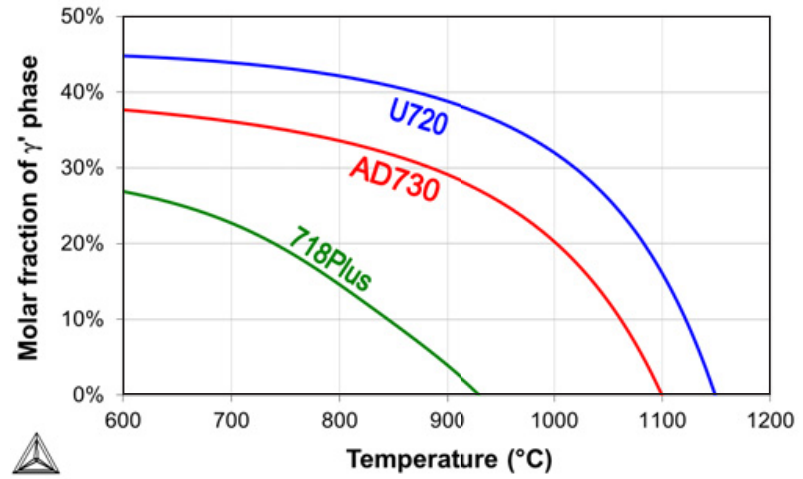

Figure 3. Gamma prime fraction at the equilibrium versus temperature in $\mathrm{AD} 730^{\mathrm{TM}}, 718$ Plus and $\mathrm{U} 720$.

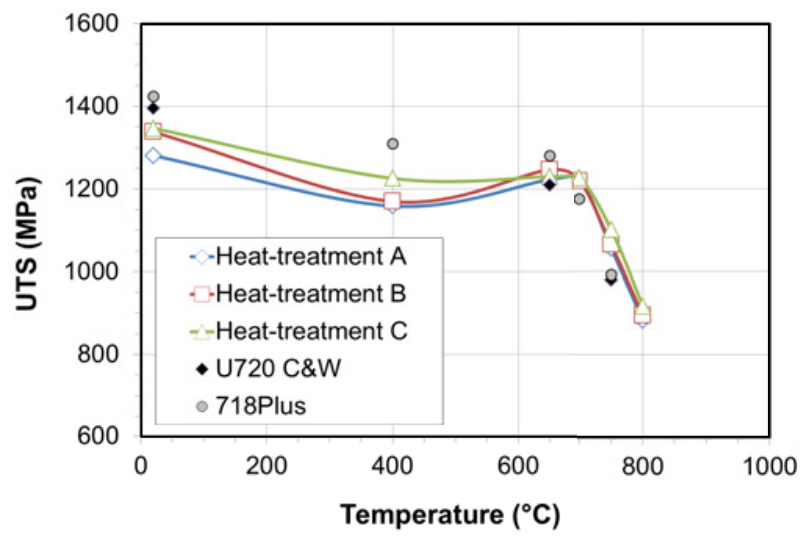

Figure 4. Ultimate Tensile Strength versus temperature.

occurred at this temperature for heat-treatment B and C and has therefore reduced the difference of creep behaviour between the three microstructures.

Creep lives obtained on coarse grain $\mathrm{AD} 730^{\mathrm{TM}}$ are in good agreement with those obtained with U720 [6] and significantly better than those obtained with 718Plus due to its finer grain size and its lower gamma prime fraction.

Low cycle fatigue tests were performed at room temperature with a strain ratio equal to -1 , a frequency equal to $0.5 \mathrm{~Hz}$, a strain range equal to $1 \%$ and a triangular wave form (Fig. 9). No significant differences were observed between heat-treatments A, B and C. Fatigue lives are assumed to be mainly governed by the grain size which is the major initiation site. As shown in Fig. 10, it is difficult to assess and to identify exactly the initiation site due to the absence of oxidation at the temperature selected for the fatigue tests. Fatigue properties were comparable and slightly lower than those obtained by those of 718Plus due to its finer grain size.

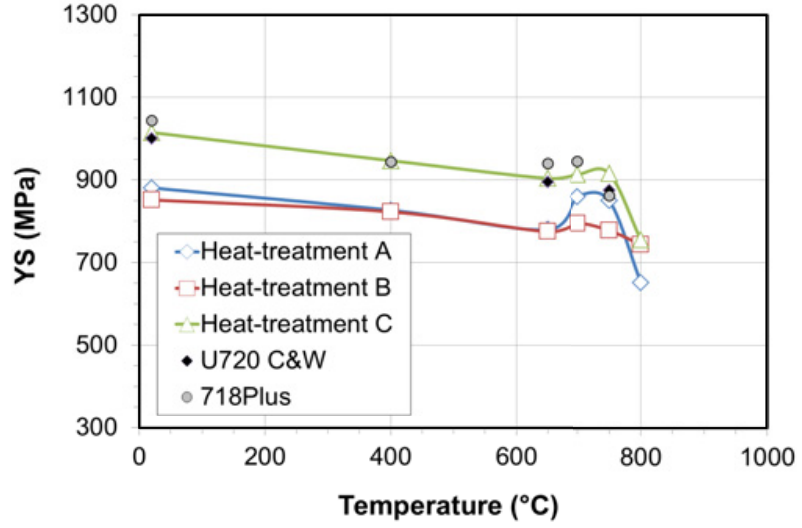

Figure 5. Yield Strength versus temperature.

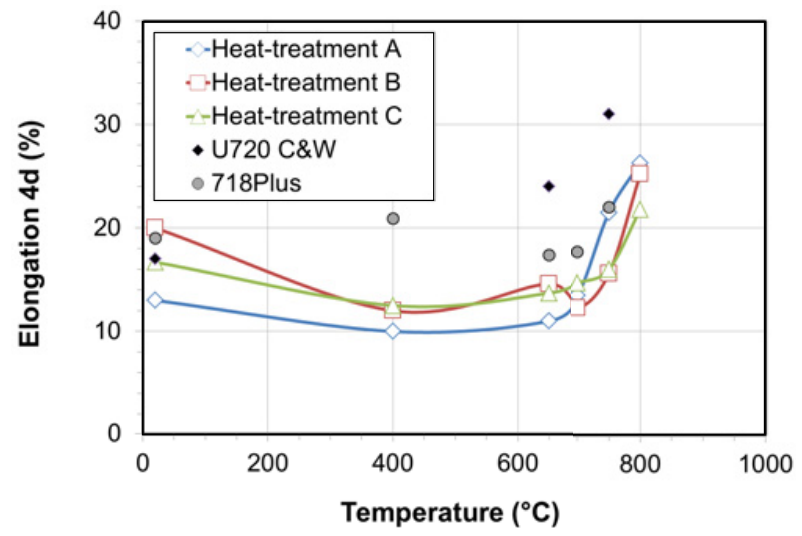

Figure 6. Elongation versus temperature.

Stress-controlled fatigue tests made at $650{ }^{\circ} \mathrm{C}$, with a ratio equal to 0.05 , a maximal stress equal to $850 \mathrm{MPa}$ and a frequency of $10 \mathrm{~Hz}$ were also performed to establish a comparison at higher temperature and fatigue cycles (Fig. 11). Similar conclusions can be made in these conditions except that the crack initiation on large favourably oriented grain can be clearly confirmed (Fig. 12).

Fatigue crack grow tests were performed in air at $650{ }^{\circ} \mathrm{C}$ with a trapezoidal wave form, a stress ratio equal to 0.1 and a hold time of $90 \mathrm{~s}$ at the peak load (Fig. 10). A good correlation is observed between the yield strength and the crack propagation rate. Fatigue crack growth rates obtained on 718Plus are in good agreement with those obtained on 718Plus supersolvus forged and presolutionned in similar conditions $[11,12]$. In comparison with 718Plus, the crack growth rate of $\mathrm{AD} 730^{\mathrm{TM}}$ is significantly lower independently of the heat-treatment. 


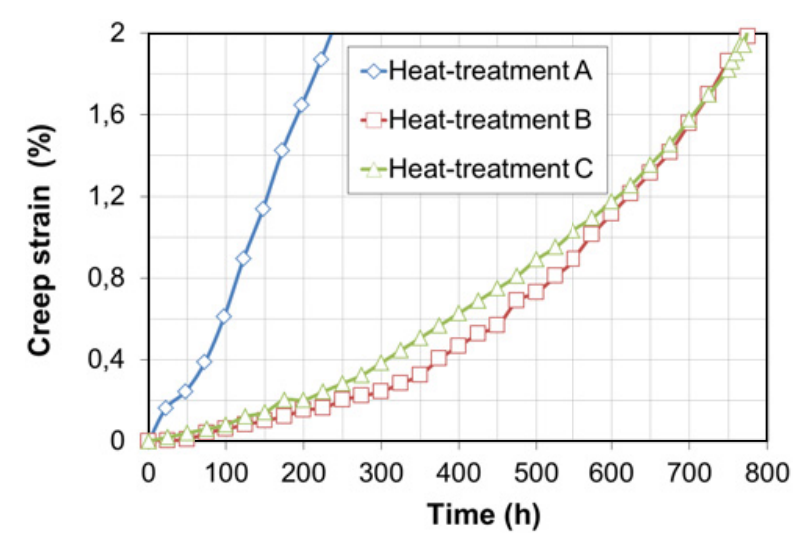

Figure 7. Creep curves obtained at $700^{\circ} \mathrm{C}-600 \mathrm{MPa}$.

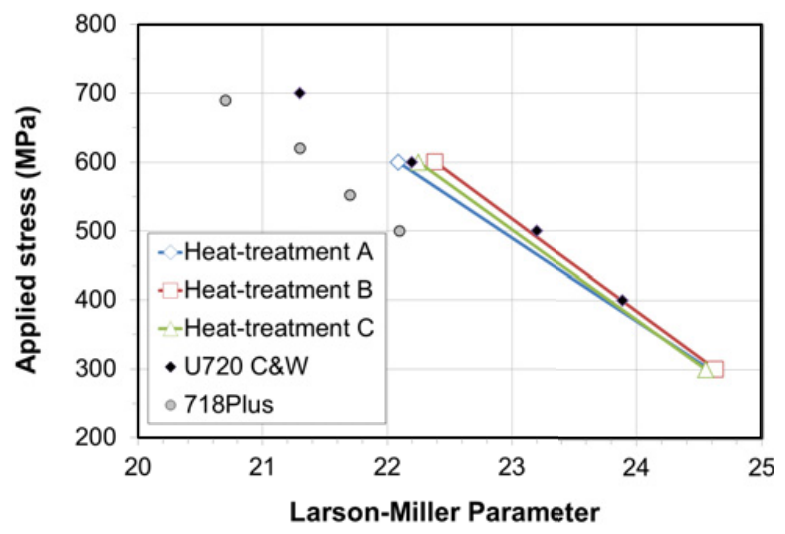

Figure 8. Creep rupture properties for different heat-treatments.

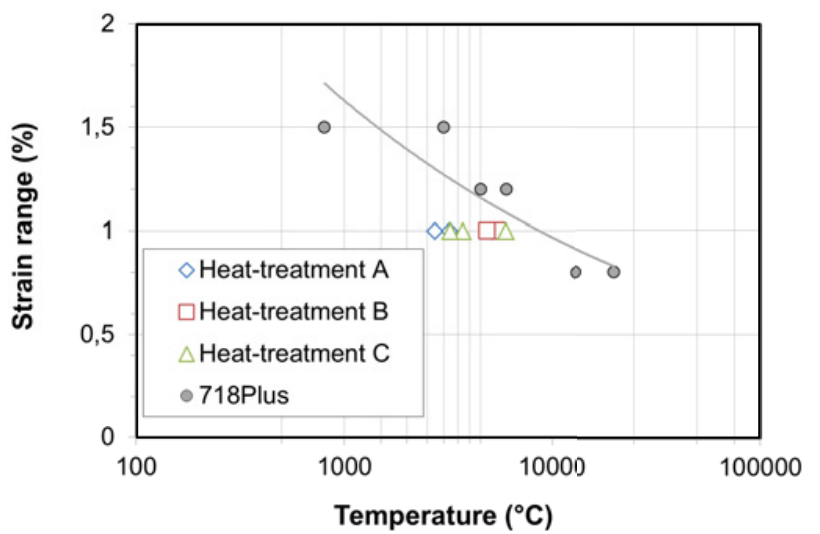

Figure 9. $\mathrm{LCF}$ properties at $20^{\circ} \mathrm{C}$ with $\mathrm{R}=-1$ for different heat-treatments.

Heat-treatment C confers a good combination of mechanical properties with the highest tensile and creep properties. Fatigue properties seem to be mainly driven by grain size but it can be expected that high yield of heattreatment $\mathrm{C}$ strength promotes longer fatigue lives for a higher number of fatigue cycles. Fatigue crack growth rates of $\mathrm{AD} 730^{\mathrm{TM}}$ supersolvus heat-treated are very low even in presence of $90 \mathrm{~s}$ hold time for each heat-treatment.

U720 coarse grain is a good reference in terms of creep properties for turbine disk applications. However, it is known that this alloy is difficult to process and not capable of large disks with the cast \& wrought route due to segregation and workability issues. It is the reason why

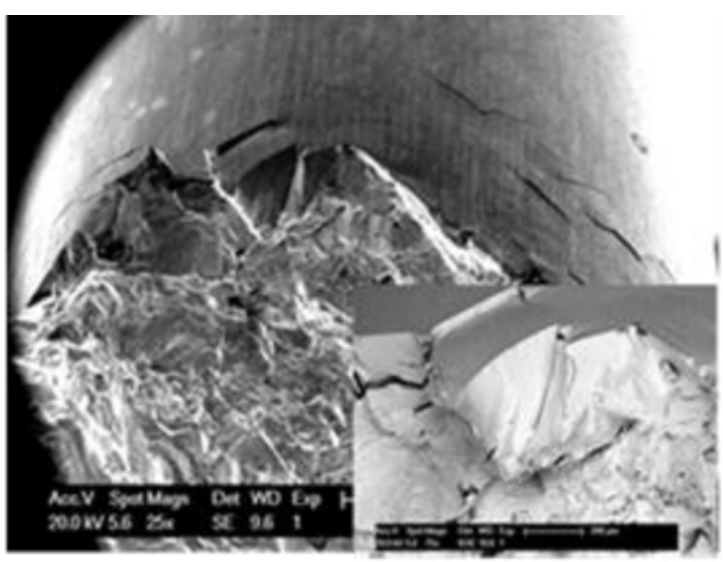

Figure 10. Fractography made on LCF specimens tested at $20^{\circ} \mathrm{C}$ with $\mathrm{R}=-1$.

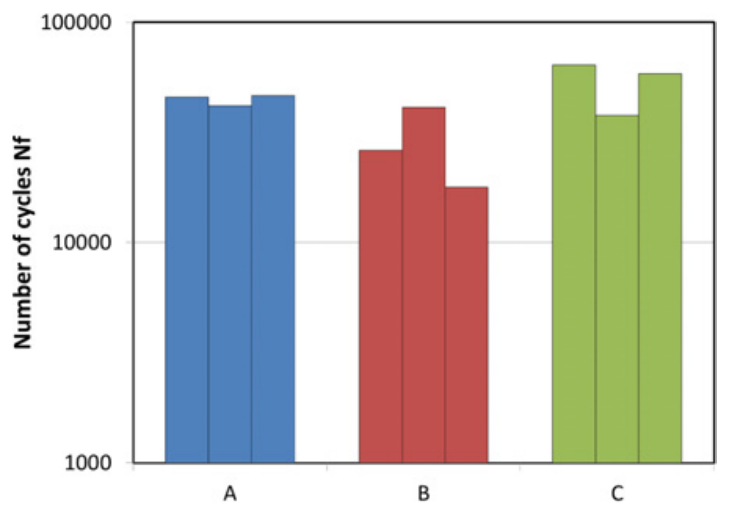

Figure 11. Fatigue properties at $650^{\circ} \mathrm{C}$ for different heattreatments.

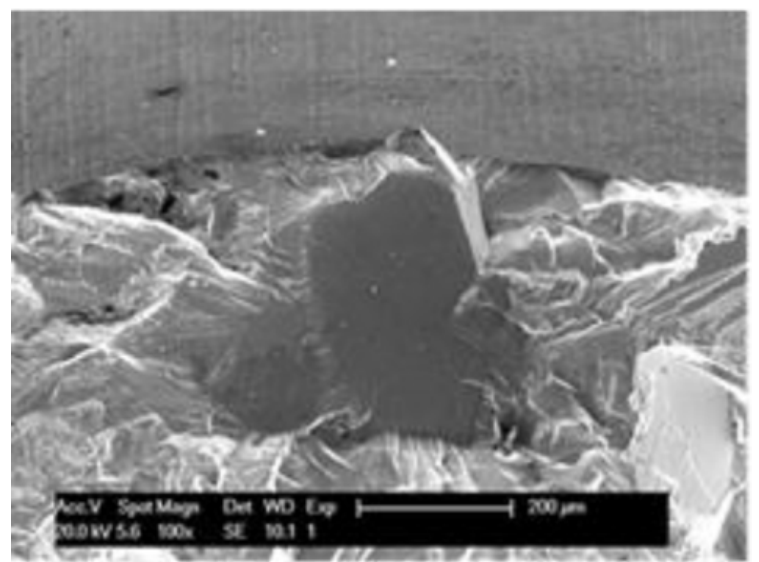

Figure 12. Fractography made on fatigue specimens tested at $650^{\circ} \mathrm{C}$.

some investigations were performed on large parts with powder-metallurgy process to avoid these issues [6]. In comparison with $\mathrm{U} 720$, AD $730^{\mathrm{TM}}$ offers the capability to manufacture large disks with similar performance and for a lower cost due to its better ability for the $\mathrm{C} \& \mathrm{~W}$ route than U720. Mechanical properties of $\mathrm{AD} 730^{\mathrm{TM}}$ supersolvus heat-treated are close to those obtained on coarse grain U720. Compared to 718Plus, which has also a better ability for $\mathrm{C} \& \mathrm{~W}$ process route than $\mathrm{U} 720, \mathrm{AD} 730^{\mathrm{TM}}$ presents a significant improvement of creep and fatigue crack growth 


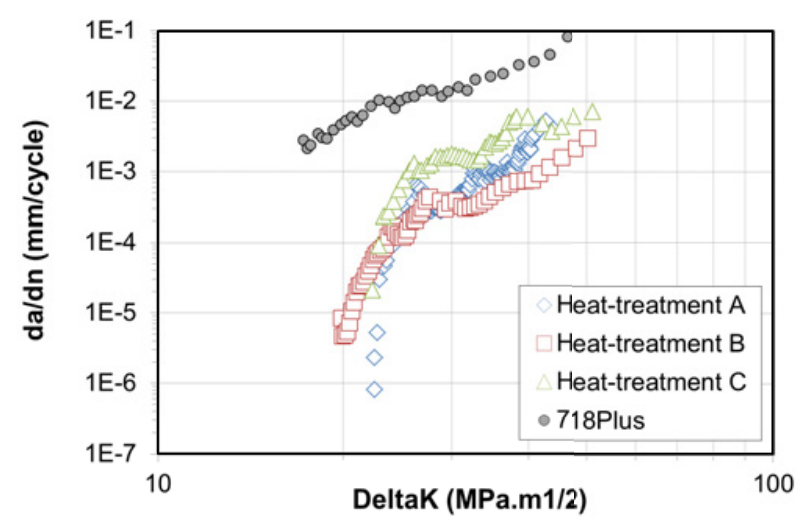

Figure 13. FCGR properties at $650^{\circ} \mathrm{C}$ with $\mathrm{R}=0.05$ and a dwell time of $90 \mathrm{~s}$ for different heat-treatments

rate properties for similar tensile strength (YS close to $900 \mathrm{MPa}$ at $700^{\circ} \mathrm{C}$ ).

\section{Conclusion}

A heat-treatment study was made on $\mathrm{AD} 730^{\mathrm{TM}}$ to evaluate the mechanical properties obtained with a coarse grain microstructure.

A homogeneous and coarse grain microstructure was obtained after a solution heat-treatment at $1120^{\circ} \mathrm{C}$. Significant variations of gamma prime precipitation were observed with the heat-treatments investigated. A high tensile and creep strength combination was especially obtained with a double solution heat-treatment, including a first step above gamma prime solvus and a second one below gamma prime solvus, which leads to the finest intragranular gamma prime sizes.

Mechanical properties obtained on $\mathrm{AD} 730^{\mathrm{TM}}$ with coarse grain microstructure were similar to those obtained on supersolvus heat-treated U720 and higher than those of supersolvus forged 718Plus.
$\mathrm{AD} 730^{\mathrm{TM}}$ properties obtained with coarse grain microstructure enable applications for power generation gas turbine disks and offers a high combination between properties and cost for such applications.

Authors wish to thank the Imphy Research Center of APERAM for the quality of the SEM-FEG observations.

\section{References}

[1] A. Devaux, E. Georges, P. Heritier, Adv. Mat. Res. 278, 405 (2011)

[2] A. Devaux, E. Georges, P. Heritier, $7^{\text {th }}$ Int. Symp. Superalloy 718 and Derivatives, 223 (2010)

[3] A. Devaux, B. Picque, M.F. Gervais, E. Georges, T. Poulain, P. Heritier, $12^{\text {th }}$ Int. Symp. Superalloys, 911 (2012)

[4] D. Locq, P. Caron, S. Raujol, F. Pettinari-Sturmel, A. Coujou, N. Clément, Superalloys 2004, 179 (2004)

[5] B. Flageolet. A\&D Internal report (2010)

[6] R Couturier, H Burlet, S Terzi, S Dubiez, L Guetaz, G Raisson, Superalloys 2004, 352 (2004)

[7] J. Mao, K-H. Chang, W. Yang, K. Ray, S.P. Vaze, D.U. Furrer, Met. Trans. A, 32A, 2441 (2001)

[8] J.Y. Guedou, J.C. Lautridou, Y. Honnorat, Superalloys 1992, 267 (1992)

[9] P.R. Bhowal, E.F. Wright, E.L. Raymond, Met. Trans. A, 21A, 1709 (1990)

[10] I. Dempster, W-D. Cao, R. Kennedy, B. Bond, J. Aurrecoechea, M. Lipschutz, $6^{\text {th }}$ Int. Symp. Superalloy 718 and Derivatives, 155 (2005)

[11] X. Liu, J. Xu, N. Deem, K.M. Chang, E. Barbero, WD. Cao, R.L. Kennedy, $6^{\text {th }}$ Int. Symp. Superalloy 718 and Derivatives, 223 (2005)

[12] R.M. Kearsey, J. Tsang, P. Au, S. Oppenheimer and E. McDevitt, $7^{\text {th }}$ Int. Symp. Superalloy 718 and Derivatives, 781 (2010) 